\title{
The potential targets of Kupffer cells activity during liver regeneration
}

\author{
M. Obolenskaya
}

Institute of Molecular Biology and Genetics National Academy of Sciences of Ukraine Zabolotnogo str. 1.50, $252143 \mathrm{Kiev}$, Ukraine

\begin{abstract}
This paper addresses possible causal and kinetic correlations between production of biologically active molecules by Kupffer cells and biochemical events in regenerating liver after partial hepatectomy. The expression and activity of some genes and enzymes were evaluated that are potential targets for regulation by Kupffer cells, e. g. transcriptional factors coded by the nuclear protooncogenes, c-fos and c-myc, a tissue-specific gene P45OIIEI and 2'5'oligo(A) synthetase. The results were compared with data about Kupffer cell activity during regeneration. Kupffer cells manifest their specific activities during transition of hepatocytes from quiescence to the first cell cycle and during the promotion of the last one. After termination of these functions the macrophages themselves enter into a cell cycle. These phenomena indicate a regulatory role of mesenchymal cells in triggering and promoting liver regeneration.
\end{abstract}

Introduction. An intriguing question of contempory research on liver regeneration is the particular role of sinusoidal non-parenchymal cells. They not only participate in the growth processes by increasing their number but also must be seen as participants in the metabolism of the whole regenerating organ and in the cross-talk with hepatocytes. This relation has not yet been well elucidated. Several points argue in favor of a participation of Kupffer cells $(\mathrm{KC})$ that produce numerous mediators [1]. With regard to the regenerating process, their activation prior to partial hepatectomy (PHE) accelerates, their inhibition delays the restoration of the parenchyma [2]. Animals with genetically altered sensitivity to lipopolysaccharide (LPS) manifest weaker response to PHE [3]. The pattern of produced mediators changes in the course of regeneration, e. g. medium conditioned by $\mathrm{KC}$ obtained during the first $12 \mathrm{~h}$ after PHE stimulates DNA synthesis in hepatocytes [4] while that from nonparenchymal cells obtained on the second day after operation delays it [5]. The expression and activity of some genes and enzymes were evaluated that are potential targets for regulation by Kupffer cells [6]. The results were compared with data about Kupffer cell activity during regeneration.

$C-F o s$ is a ubiquitous nuclear phosphoprotein that together with $c$-Jun forms stable heterodimer known

(C) M. OROLENSKAYA, 1997 as the transcriptional activator protein (AP-1). AP-1 possesses a dual function activating not only transcription but DNA replication [7]. AP-1 activity is regulated by wide spectrum of stimuli, including cytokines and growth factors.

$C-M y c$ is a nuclear phosphoprotein that together with $c$-Max forms a transcriptional factor. The functional activity of $c-M y c$ is regulated at transcriptional, posttranscriptional and posttranslational levels. $c-M y c$ is critical for proliferation/differentiation balance and cell cycle progression especially during $\mathrm{G} 1$ and S-toG2/M phase [8].

P450IIE1 is a microsomal enzyme involved in metabolism of foreign compounds. Cytokines IL-1, IL-6, TNF- $\alpha$ and IFN $\alpha / \beta$ downregulate its expression [9]. 2'5'oligo(A)synthetase is a limiting enzyme of $2^{\prime} 5^{\prime}$ oligo(A) synthetase/RNAse L system negatively regulating the amount of RNA at the pretranslational level. The $c$-myc RNA is a potential target of the system. Cytokines IFN $\alpha / \beta$ and TNF- $\alpha$ positively regulate enzymes expression $[6,10]$.

The most reliable time marker of regenerating process is the DNA synthesis in the liver cells. Hepatocytes, KC and sinusoidal endothelial cells enter their first cell cycles in the given order [11]. The S phase of hepatocytes (ca. 12-25 $\mathrm{h}$ after PHE) is preceeded by prereplicative period conveniently subdivided into immediate-early response (ca. $0.5 \mathrm{~h}$ after $\mathrm{PHE}$ ), delayed reaction with metabolic 
reorientation providing competence to proliferate (ca. $0.5-3 \mathrm{~h}$ after $\mathrm{PHE}$ ) and a $\mathrm{G}$ l-like period (ca. $3-12$ $h$ after PHE) [12]. The G2 and $M$ phases in hepatocytes have standard periods of $4.5 \mathrm{~h}$ and $1 \mathrm{~h}$, respectively.

Materials and Methods. Pretreatment of the animals. Male Wistar rats $(150-200 \mathrm{~g})$ were used throughout. Partial (2/3) hepatectomy and sham operation were performed by standard procedure. Livers were perfused in situ at the time indicated with cold physiological saline and were processed either immediately or frozen and stored at $-70^{\circ} \mathrm{C}$ before usage.

Detection of relative amount of specific $R N A$. Total RNA from nuclear and cytoplasmic (S10) liver fractions was isolated by a slightly modified guanidinium isothiocyanate method. Poly (A) ${ }^{+}$cytoplasmic RNA was separated on oligo(dT) cellulose, the relative amount of specific RNAs was registered by dot-, blot hybridizations in the presence of formamide. The probes were radioactively labeled with $~^{32} \mathrm{P} \mathrm{J}-\mathrm{dCTP}$ in nick-translation or randomly primed reactions. The intensity of hybridization signals was registered in autographs with a laser scanner. The following probes were used: the PstI fragment $(1100 \mathrm{bp})$ of the $v-f o s$ gene, the $X b a I-S a c I$ fragment of murine $c-m y c$ cDNA and the PstI fragment (300 bp) of murine P450IIEl cDNA.

Detection of 2'5'oligo( $A$ )synthetase activity. Enzymatic activity of the nuclear (S12) and cytoplasmic (S15) fractions was detected using the specific binding activity of polyl-polyC paper and catalytic activity of bound enzyme. $2^{\prime} 5$ 'oligo(A) adenylates were synthesized in the presence of $\left[{ }^{14} \mathrm{C}\right]-\mathrm{ATP}$ and were separated by chromatography on PEI-cellulose. Their radioactivity was measured [13].

Results. The relative amounts of $c-f o s, c-m y c$ and P450IIEI specific RNAs. Nuclear and poly (A) ${ }^{+} c y-$ toplasmic RNAs from intact, regenerating and sham operated liver produced hybridization signals with each of these probes. The nuclear RNAs existed as precursor molecules of greater molecular weight (data not shown). The time course of changes is specific for each RNA. The kinetics of nuclear and poly (A) ${ }^{+}$ cytoplasmic P450IIE1 RNA are similar - the upregulation during the first three hours after PHE is followed by down-regulation during $6-24 \mathrm{~h}$ interval and slight increase later on (fig. 1,4). This coincidence suggests the prevalence of transcriptional over posttranscriptional control of gene expression. Downregu lation during late $\mathrm{Gl}-\mathrm{S}$ phase of hepatocytes correlates with resistance of regenerating liver to he patotoxins [14]. Nuclear $c-f o s$ and $c-m y c$ specific RNAs are up-regulated with the maxima at $3 \mathrm{~h}$ and ca. $18 \mathrm{~h}$ after PHE (fig. 2). Their counterparts in poly $(\mathrm{A})^{+}$cytoplasmic RNA do not follow the same time course (fig. 3), especially during the prere-

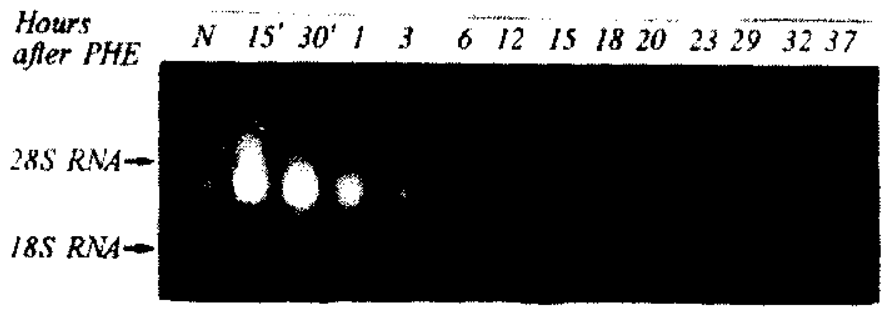

Fig. 1. Hybridization signals of P450IIE1 cytoplasmic RNA in regenerating liver

plicative period; this raises the questions about an involvement of posttranscriptional events in the regulation of these genes. Both poly (A) ${ }^{+}$RNAs are downregulated after their immediate increase after PHE, later on, the relative amount of $c-m y c$ RNA is elevated during the G1-to-G1/S and S-to-G2/M transitions (fig. 3), that of $c$-fos RNA during the $S$ phase of hepatocytes (fig. 4). Immediate-early transient expression of $c$-fos and $c-m y c$ transcripts is well documented for different cells in particular for mitogen-stimulated hepatocytes [15]. The expression of these genes during the later periods of regeneration remains to be clarified. The increase of $c$-fos transcripts during the $S$ phase of hepatocytes implicates $c-F o s$ participation in DNA synthesis or related

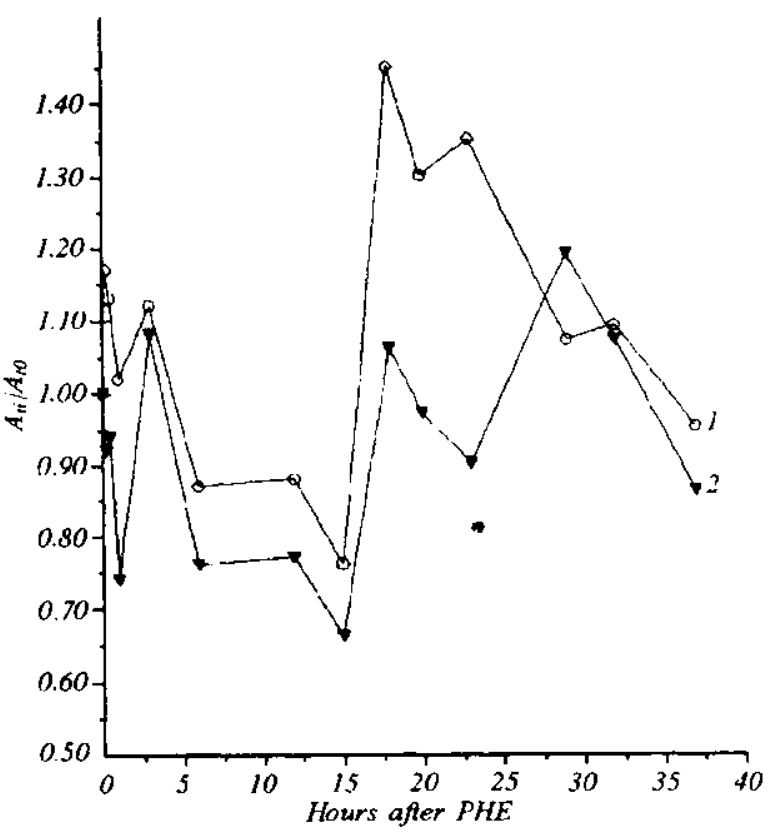

Fig. 2. Relative amount of $c-f o s(I)$ and $c-m y c$ (2) RNA in nuclear RNA from regenerating liver 


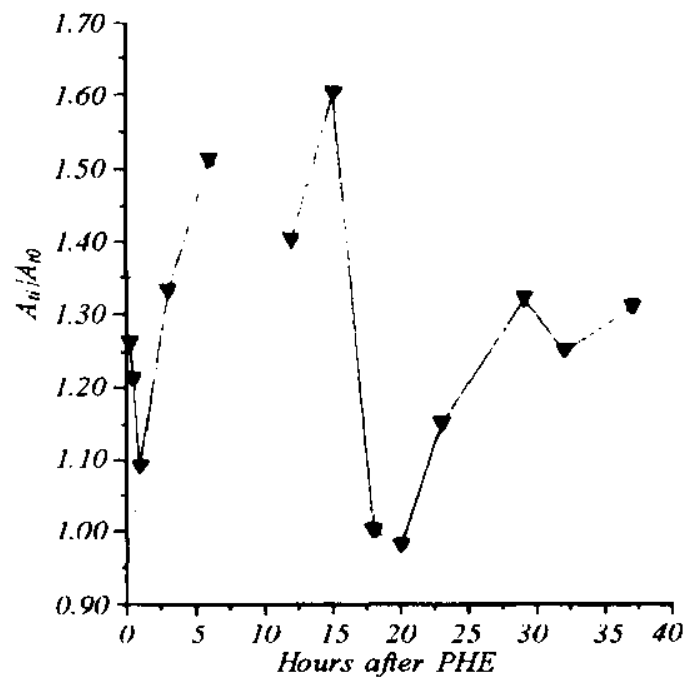

Fig. 3. Relative amount of $c-m y c$ RNA in cytoplasmic RNA from regenerating liver

processes and correlates with activating role of AP-1 in DNA replication $[7]$. The time-course of $c-m y c$ transcripts in regenerating liver resembles the similar changes of $c-M y c-c-M a x$ transcriptional activity and phosphorylation pattern of $c-M y c$ in proliferating cells [8].

$2^{\prime} 5^{\prime}$ oligo( $A$ ) synthetase activity after PHE. Enzyme activity was detected in nuclear and cytoplasmic fractions, the nuclear specific activity being higher by

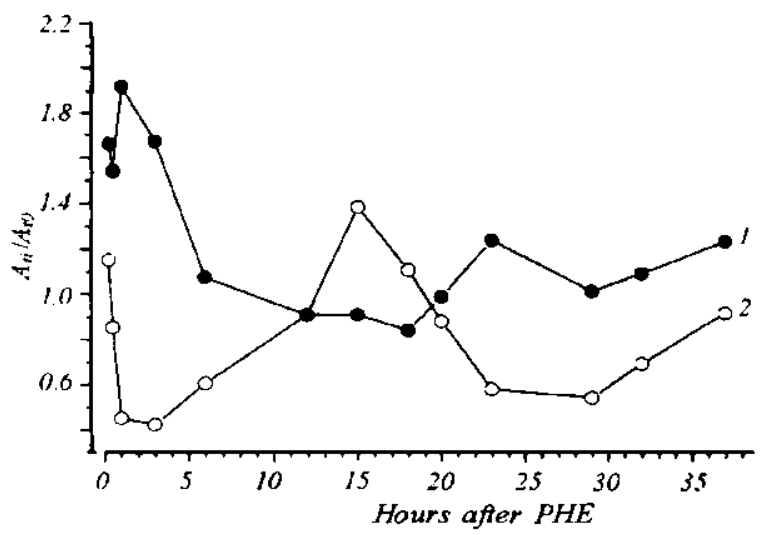

Fig. 4. Relative amount of P450IIEI ( $l$ ) and $c$-fos (2) RNA in cytoplasmic RNA from regenerating liver one order (fig. 5). Taking into account the distribution of the cellular protein between both fractions, their input to the total cellular enzymatic activity is nearly equal. PHE induced a temporal decrease in nuclear activity with minimum at $3 \mathrm{~h}$ (compare the up-regulation of $c$-fos, $c-m y c$ and P450IIE1 nuclear transcripts at this time (fig. 2), and an increase in the cytoplasmic activity with a maximum at $0.5 \mathrm{~h}$ after PHE (compare the simultaneous decline of c-myc transcripts in cytoplasm) (fig. 3). It should be noted that the reorganization of ribosomal machinery occurs also at $0.5 \mathrm{~h}$ after operation. The ribosomes transiently lose attachment to the rough endoplasmatic reticulum. The restoration of the typical structure of the latter begins $1 \mathrm{~h}$ after PHE [12].

Discussion. The biological activities of mediators, their availability in each period of the process and the corresponding biochemical events in regenerating liver have been analyzed. The available evidences about $\mathrm{KC}$ activity during liver transition from quiescence to proliferation and during their first cell cycle are summarized in table. The production of thromboxane $A_{2}\left(T \times A_{2}\right)$ was up-regulated during the immediateearly response (see table); this eicosanoid is produced in the liver mainly by $\mathrm{KC}$ from the endogenous pool of bound arachidonic acid in response to $\mathrm{KC}$ stimulation by phagocytosis or intracellular $\mathrm{Ca}^{++}$elevation [1]. The ability of thromboxane to induce glycogenolysis, platelet activation and sinusoids construction $[1]$ is in line with the processes occuring at this time in the liver [16]. The nature of the earliest up-regulation of nuclear protooncogenes expression is not yet clear.

During the delayed-early response, the action of potent cytokines, e. g. TNF- $C$ and IL-1 $|17-20|$, and

Kupffer cells activity in regenerating liver

\begin{tabular}{|c|c|}
\hline Periods & Medialors \\
\hline Immediate-early & $\mathrm{TxA}_{2}$ \\
\hline Delayed-early & $\begin{array}{l}\text { TxA2, PGE2, PGF } 2 \alpha, \text { TNF- } \alpha \text {, } \\
\text { IL }-1 \alpha, \mathrm{IL} 1-\beta, \text { IFN } \alpha / \beta\end{array}$ \\
\hline \multicolumn{2}{|l|}{ Cell cycle of $\mathrm{HC}$} \\
\hline GI & $\begin{array}{l}\text { PGE2, PGF } 2 \alpha, \text { TNF }-\alpha, \text { INF } \alpha / \beta, \\
\text { TGF } \alpha^{*}, \text { TGF } \beta^{*}\end{array}$ \\
\hline$S$ & PGE2, IL-6* \\
\hline G2-G2/M & PGE2, TGF $\beta^{*}$ \\
\hline \multicolumn{2}{|l|}{ Cell cycle of $\mathrm{KC}$} \\
\hline G1 & PGE2, TGF $\beta^{*}$, NO \\
\hline
\end{tabular}

*The mediators potentially produced by $\mathrm{KC}$. The role of $\mathrm{KC}$ in their production is not yet proved for regenerating liver. 


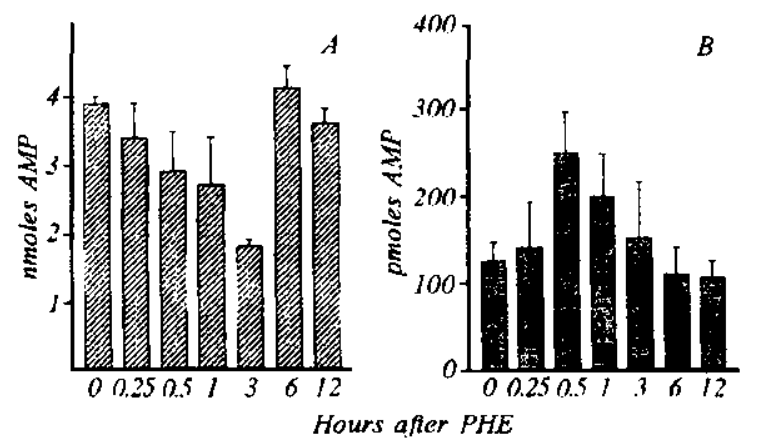

Fig. 5. 2'5'oligo(A)synthetase activity in nuclei $(A)$ and cytoplasm $(B)$ in regenerating liver

the increased responsiveness to them due to elevated expression of TNF receptors [17] may define the whole set of observed events, e. g. up-regulation of $c$-fos- and $c$-myc- and down-regulation of P450IIE1 expression, as demonstrated here, NO production in hepatocytes as shown previously $[21,22]$, proinflammatory and hepatocyte-specific promitogenic reactions, and autostimulation of $\mathrm{PGE}_{2}$ synthesis $[23$, $24 \mathrm{l}$. Prostaglandin $E_{2}$ is instrumental in the regulation of cytokine production [23], the increase of intracellulr cAMP [23], in relaxation of sinusoids and consequently enhanced blood flow in the liver [25]. IFN $\alpha / \beta$ and TNF- $\alpha$ are potential regulators of $2^{\prime}, 5$ 'oligo(A) synthetase activity $[10]$, but differential regulation of enzyme in nucleus and in cytoplasm points to the complexity of this regulation.

During the Gl-like period, the set of acting cytokines enlarged by the two complete mitogens, transforming growth factor $\alpha$ and hepatocyte growth factor (HGF); counteracting is TGF- $\beta$, an inhibitor of DNA synthesis $\{15]$. They originated in regenerating liver from hepatocytes, endothelial cells and hepatic stellate cells, respectively $[15]$. Whether and to what extent $\mathrm{KC}$ are implicated in this synthesis is not yet clear. Their role as stimulators of HGF expression via TNF- $\alpha$, however, is established [25]. The up-regulation of $c$-fos and $c-m y c$ expression, the sustained down-regulation of P450IIE1 gene expression and the enhanced production of NO by hepatocytes are consistent with an involvement of $\mathrm{KC}$.

During the $S$ phase of hepatocytes $\mathrm{KC}$ activity slowly declines. The progressively increasing production of $\mathrm{PGE}_{2}$ seems to inhibit TNF- $\alpha$ and IL-1 syntheses by $\mathrm{KC}[1]$. The liver macrophages obtained at this time synthesize in vitro less cytokines than the cells from sham-operated animals while blockade of cyclooxygenase pathway greatly activates them [24]. The involvement of $\mathrm{KC}$ in stimulation of $\mathrm{IL}-6$ synthesis at this or previous stage is also likely [19]. IL-6 is the most potent regulator of the acute phase response that temporally coincides with the $S$ phase [27]. Despite the fact that stimulated KC produce IL-6 [1], their involvement in synthesis occuring in regenerating liver has not yet been proved.

Two other sets of evidences complete the scheme of regenerating process. Previously, we have shown that NO production coincides with the entrance of hepatocytes into the cell cycle [21]. While NO production in hepatocytes is under cytokines control [22], NO synthesis in activated $\mathrm{KC}$ is under $\mathrm{PGE}_{2}$ control [1 ]. It seems likely that the high level of $\mathrm{PGE}_{2}$ triggers NO production in $\mathrm{KC}$ manifesting their entrance into the cell cycle. Endogeneous NO is known as inhibitor of cyclooxygenase pathway and IL-6 producion in KC [28]. If it is also the case in the regenerating liver, the paracrine activity of $\mathrm{KC}$ is suppressed giving the way for the cell cycle-connected processes.

Thus, the cell-specific actions of Kupffer cells provide the regulatory network in the regenerating liver. The synergism between cell-specific functions of Kupffer cell and non-parenchymal cells in general and proliferative activity of hepatocytes is a key mechanism of liver regeneration. This statement is compatible with the general idea about the regulatory role of mesenchymal cells in the functioning of epithelial cells.

Acknowledgement. We are thankful to prof. Alexei Ryskov and prof. Peter Chumakov (Institute of Molecular Biology, Russian Academy of Sciences, Moscow) for the probes of P450IIE, $c$-fos and c-myc cDNAs, that were kindly provided, to L. Pater and L. Sazonova for excellent technical assistance and to Prof. K. Decker (Albert-Ludwig University, Freigurg, Germany) for reading the manuscript and useful notices.

\section{М. Ю. Оболенська}

Взаємозв'язок активності клітин Купфера та біохімічних процесів у регенеруючій печінці

Резюме

Цю роботу присвячено аналізу причинно-наслідкових зв'язків та часових співвідночень між синтезом клітинами Купфера біологічно активних молекул $і$ біохімічними процесами, ио проходять у регенеруючій печінці після часткової сепатектомї̈. Досліджували експресію $i$ активність ряду сенів $i$ ферментів, які потенційно ресулюються клітинами Купфера, а саме: протоонкоенів c-fos i c-тус, кодуючих транскрипційні фактори, тканиноспецифічного гена P450IIEI $i$ ферменту 2'.5'-оліго (А)синтетази. Синтез біологічно активних молекул в клітинах Купфера с найвиразнішим у період переходу сепатоцитів від стану спокою до ділення. По мірі проходження zепатоцитами фаз клітинного циклу набір біолосічно активних молекул звужусться. Клітини Купфера переходять до проліферації після завериення гепатоцитами їх першого 
клітинного ціклу. Пропонується сіпотеза щодо регулюючої ролі клітин Купфера в запуску і розвиткові регенераційного процесу у печінці.

\section{М. Ю. Оболенская}

Взаимосвязь активности клеток Купфера и биохимических процессов регенерирующей печени

\section{Peфepat}

Настоямая работа посвячена анализу причинно-следственных связей и временных соотношений между синтезом клетками Купфера биологически активных молекул и биохимическими процессами, происходящими в регенерирующей печени после частииной гепатэктомии. Нсследовали экспрессию и активность ряда ценов и ферментов, потенциально ресулируемых клетками Купфера, а именно: протоонкоценов c-fos и с-тус, кодирующих транскрипционные факторы, тканеспецифического гена P450IIEI и фермента 2',5'-олиго (A)синтетазы $\mathrm{Pe}$ зультаты исследований сравнивали с данными об активности клеток Купфера во время регенерации Синтез биологически активных молекул в клетках Купфера наиболее вырахен ө nериод перехода гепатоцитов от покоя к делению. По мере прохождения гепатоцитами фаз клеточного цикла набор биологически активньх молекул сужается. Клетки Купфера переходят к пролиферации после завершения гепатоцитами их первого клеточного цикла. Предлагается гипотеза о регулирующей роли клеток Купфера в запуске и развитии регенерационного процесса в печени.

\section{REFERENCES}

I. Decker K. Biologically active products of stimulated liver macrophages (Kupffer cells) // Eur. J. Biochem.-1990.192.-P. 245-261.

2. Mayanskii D. N., Scherbakov $K$. Hepatocyte regeneration following Kupfer cells stimulation with prodigiosan // Biull. Eksp. Biol. Med. - 1978.-86. -P. 69-71.

3. Cornell $R$. P. Restriction of gut-derived endotoxin impairs DNA synthesis for liver regeneration // Amer. J. Physiol.-1985.249. - P. R563-R569.

4. Katsumoto F., Miyazaki $K$., Nakayama $F$. Stimulation of DNA synthesis in hepatocytes by Kupffer cells after partial hepatectomy // Hepatology.-1989.-9.-P. 405-410.

5. Woodman A. C., Selden C. A., Hodgson H. J. F. Partial purification and characterization of an inhibitor of hepatocyte proliferation derived from nonparenchymal cells after partial hepatectomy // J. Cell. Physiol.-1992.-151.-P. 405-414.

6. Kronke M., Schutze S., Scheurich P., Pfizenmaier $K$. TNF signal transduction and TNF-responsive genes // Tumor Necrosis factor / Eds B. B. Aggarwal, J. Vilcek, K. Dekker.-New York: Basel; Hong Kong, 1992.-P. 189-216

7. Karin $M$. The regulation of AP-1 activity by mitogen-activated protein kinases // J. Biol. Chem.-1995.-270.-P. 1648316486

8. Seth A., Gupta S., Davis $R$. Cell cycle regulation of the $c-M y c$ transcriptional activation domain // Mol. Cell. Biol.-1993.13. -P. $4125-4136$.

9. Razzak Z. A., Loyer P., Fautrel A. et al. Cytokines down-regulate expression of cytochromes P-450 from families $1 \mathrm{~A}, \mathbf{2 C}$ and $3 \mathrm{~A}$ in human hepatocyte cultures // Regulation of liver gene expression in health and disease / Eds S. Woo et al.-New York: Cold Spring Harbor Lab., 1993.-P. 68.

10. Pestka S., Langer J., Zoon K. C., Samuel C. E. Interferons and their actions // Ann. Rev. Biochem.-1987.-56.-P. $727-777$.

11. Widmann J. J., Fahimi H. D. Proliferation of mononuclear phagocytes (Kupffer cells) and endothelial cells in regenerating rat liver // Amer. J. Pathol- - 1975. - 80. -P. 349-360.

12. Obolenskaya M. Yu, Prima V. I., Gerasimova T. B., Platonov $O$. $M$. Partial restriction of genome expression as a component of its work in regenerating liver of mammals // Biopolimeru $i$ kletka. -1989.-5.-P. 79-88.

13. Etienne-Smekens M., Vandenbussche P., Content J., Dumon $J .\left(2^{\prime}-5^{\prime}\right)$ oligoadenylate in rat liver: Modulation after partial hepatectomy // Proc. Nat. Acad. Sci. USA.-1983.80.-P. 4609-4613.

14. Uruvaeva I. V., Faktor V. M. Interrelation of division and cellular function. Liver resistance to toxic influence of $\mathrm{CCL}_{4}$ after partial hepatectomy $/ /$ Cytologia.-1976.-18.P. 1354-1359.

15. Fausto N., Webber E. Liver regeneration // The Liver Biology and Pathobiology / Eds J. M. Arias, J. L. Boyer, N. Fausto et al.-New York: Raven press, 1994.-P. 1059-1084.

16. Becker $F, F$. Acute glycogenolysis: a major stimulus of autophagocytic activity in rat hepatocytes // Proc. Soc. Exp. Biol. Med.-1972.-140.-P. 1170-1172.

17. Obolenskaya $M$. Yu., Bernauer H., Tran-Thi T. A., Decker $K$. Levels of RNA for TNF $\alpha$ and TNF receptors during the prereplicative period of liver regeneration // Biopolimera $i$ kletka.-1994.-10. - P. 68-77.

18. Satoh M., Adachi K., Suda $T$. et al. TNF-derived inflammation after partial hepatectomy and its role in growth regulation of liver // Mol. Biotherapy. $-1991,-3 .-P .136-147$.

19. Akerman P., Cote P., Yang $S$. $Q$. et al. Antibodies to tumor necrosis factor- $\alpha$ inhibit liver regeneration after partial hepatectomy // Amer. J. Physiol._1992.-263.--P. G579G585.

20. Higashitsuji H., Arii S., Furutani M. et al. Expression of cytokine genes during liver regeneration after partial hepatectomy in rats // J. Surg. Res.-1995.-58.-P. 267-274.

21. Obolenskaya M., Schulze-Specking A., Plaumann B. et al. Nitric oxide production by cells isolated from regenerating rat liver // Biochem. and Biophys. Res. Communs.-1994.204. -P.1305-1311.

22. Curran R. D., Billiar T. R., Stuehr J. et al. Multiple cytokines are required to induce hepatocyte nitric oxide production and inhibit total protein synthesis // Ann. Surg. - 1990,-212.P. 462- 469 .

23. Decker $K$. The regulatory role of prostaglandins in the challenged liver // Lipid Mediators in Health and Diseases / Ed. H. Zor.-Freund Publ. House, 1994.-P. 133-137.

24. Callery $M . P$., Kamei $T$., Flye $M$. W. Kupffer cell tumor necrosis factor-alpha production is suppressed during liver regeneration // J. Surg. Res. - 1991.-50.-P. 515-519.

25. Kawada $N$., Inoue $M$., Decker $K$. The construction of stellate cells exposed to sinusoidal cell-derived vasoactive substances // Cells of hepatic sinusoid / Eds E. Wisse, D. L. Knook, K. Wake.-New York, 1995.-P. 165-170.

26. Tamura M., Arakaki N., Tsubouchi H. et al. Enhancement of human growth factor production by interleukin- $l \alpha$ and $-1 \beta$ and tumor necrosis factor by fibroblasts in culture $/ / \mathrm{J}$. BIol. Chem.-1993.-268.-P. 8140-8145.

27. Andus $T$., Geiger $T$., Hirano $T$, et al. Regulation of synthesis and secretion of major rat acute-phase proteins by recombinant human interleukin-6 (BSF-2/1L-6) in hepatocyte primary culture // Eur. J. Biochem. $1988 .-173 .-$ P. $287-293$.

28. Stadler J., Harbrecht B.G., Silvio M. D. Endogenous nitric oxide inhibits the synthesis of cyclooxygenase products and interleukin-6 by rat Kupffer cels // J. Leukoc. Biol.-1993.53. - P. $165-172$.

УдК 547.963 .3

Received 02.10.96 